\title{
Designing effective interventions to increase the uptake of the HPV vaccine among adolescent girls (9-14 years)
}

Pre-Analysis Plan

Submitted 27/01/2021

\author{
Abstract \\ In this study we evaluate communication-based interventions to decrease doctors' \\ hesitancy in prescribing the HPV vaccine to adolescent girls. In a field survey \\ experiment, we expose medical practitioners -- general physicians, pediatricians and \\ gynaecologists -- to a video based stimulus and collect information on attitudes, \\ intentions, before and after the intervention. We test for 5 different interventions -- \\ endorsement from trusted medical experts, providing conversational tips, \\ combining HPV vaccine prescription with other widely accepted medical \\ prescriptions, poster-based nudges, and increasing salience of risk from HPV. We \\ conduct our survey experiment with a sample of medical practitioners in West \\ Bengal using self-administered computer assisted personal interviews.
}




\section{Motivation and Research Question}

India accounts for $17 \%$ of the global cervical cancer burden, accounting for over 96,922 new cases every year. Cervical cancer is the second-leading cause of cancer deaths among women in the country, with an estimated 60,078 deaths reported annually ${ }^{6}$.

Primary prevention of cervical cancer is possible through the HPV vaccine administered to adolescent girls in the age group of 9-14 years. However, the uptake of the HPV vaccine remains low in India. It is therefore critical to focus efforts towards increasing coverage of the HPV vaccine.

According to Hassan et al., there is low awareness of cervical cancer and the HPV vaccine and a majority of people are not aware of the link between the two. Those who are aware of the vaccine are not willing to be vaccinated due to concerns regarding its safety?. However, evidence shows that healthcare providers are crucial for bridging this knowledge gap, and improving uptake of the vaccine ${ }^{2}$. This is because trust is a key element of the relationship between physicians and patients which, supplemented by strong recommendations on the HPV vaccine can significantly increase willingness to vaccinate ${ }^{3}$.

Physicians in India display varying levels of hesitancy around the HPV vaccine which affects the strength of their recommendations. Here, 'physicians' refers to paediatricians, gynaecologists and general physicians. By addressing this hesitancy and increasing physicians' confidence in recommending the HPV vaccine, we can also increase parents' conviction to vaccinate their daughters. ${ }^{4,5}$ The goal of the project is therefore to minimize HPV vaccine hesitancy on the side of physicians.

In the first phase of this project, we conducted qualitative research with a sample of 97 participants in West Bengal including physicians, decision makers, adolescent girls and some other stakeholders. Through this study, we were able to arrive at a list of barriers and facilitators to the desired behaviour i.e. physicians recommending the HPV vaccine with confidence. We then designed interventions to achieve the desired behaviour and are now conducting an experiment to test the effectiveness of five of these interventions through a research study where the overarching

\footnotetext{
${ }^{1}$ Hussain S., Nasare V., Kumari M., Sharma S., Khan M.A, et al. (2014). Perception of Human Papillomavirus Infection, Cervical Cancer and HPV Vaccination in North Indian Population. PLOS ONE 9(11).

${ }^{2}$ Montgomery M.P., Dune T., Shetty P.K., \& Shetty A.K. (2015). Knowledge and acceptability of human papillomavirus vaccination and cervical cancer screening among women in Karnataka, India. J Cancer Educ 30(1): 130-137.

${ }^{3}$ Rosenthal S.L., Weiss T.W., Zimet G.D., Ma L., Good M.B. \& Vichnin M.D. (2011). Predictors of HPV vaccine uptake among women aged 19-26: importance of a physician's recommendation. Vaccine 29(5):890-895.

${ }^{4}$ Dempsey, A. F. \& O'Leary, S. T. (2018). Human Papillomavirus Vaccination: Narrative Review of Studies on How Providers' Vaccine Communication Affects Attitudes and Uptake. Academic Pediatrics 18(2): S23-S27.

${ }^{5}$ Shay, L.A. Baldwin, A. S., Betts, A. C., Marks, E. G., Higashi, R. T. et al. (2018). Parent-Provider Communication of HPV Vaccine Hesitancy. Pediatrics 141 (6): 2017-2312.
} 
research question we aim to answer is: What behavioural interventions help reduce physicians' hesitancy to recommend the HPV vaccine? The five interventions we are testing are:

1. Physician champion: Having a trusted expert (Dr. Soumya Swaminathan 0 WHO Chief Scientist \& practicing pediatrician) endorse the HPV vaccine.

2. Communications toolkit: Providing physicians with a toolkit containing both strategies and tips that can help navigate conversations on the HPV vaccine with parents of adolescent girls.

3. Bundling: Combining conversations on the HPV vaccine with other widely adopted health behaviours (for e.g. the Td/Tdap vaccine, cervical cancer screening, or other adolescent health topics such as reducing obesity).

4. Third party nudging: Placing the onus of having conversations about the vaccine on a neutral party, such as a group of doctors or medical associations endorsing the vaccine.

5. Salience: Increasing the salience of the incidence \& risks of cervical cancer, and the efficacy of the HPV vaccine.

\section{Methods}

We are constrained to conducting a field survey experiment, due to the COVID-19 pandemic. Hence we limit our intervention collaterals to videos, as opposed to more real-world forms such as printed materials that could be handed out to doctors or placed in their clinics. We define the area of study to be West Bengal, given that we have the most support from our partner organisation in the state. General Practitioners, Gynecologists and Pediatricians form the subject pool for our study.

\section{Experimental Design}

Our research design is a simple experiment, where participants are exposed to a 2-3 minute video stimulus, bookended by a baseline and an endline measurement of outcome and control variables. We have 7 experimental arms in the study, one control arm and 6 treatment arms. Participants in the control arm are exposed to a video about Biodiversity ${ }^{67}$-- which we hypothesise will have no impact on existing attitudes or intentions towards vaccine recommendations by participants.

Participants in the treatment arms are exposed to a video based on the respective behavioural interventions, described in the previous section.

\footnotetext{
${ }^{6}$ Video can be found at

(https://www.youtube.com/watch?v=kHhspf5IfdE\&ab_channel=UNESCO)

${ }^{7}$ Participants in our pilot were exposed to a video stimulus talking about the impact of the Save The Children programme (https://vimeo.com/387880151)
} 
Each stimulus also has a supplementary image that is accessible to participants when they are answering the endline questionnaire.

The experiment is programmed on Qualtrics, and takes subjects about 30 minutes to complete. All participants self-administer the survey.

\begin{tabular}{|c|c|c|c|c|c|c|}
\hline & & & Subjects & & & \\
\hline TO: Control & T1 & $\mathrm{T} 2$ & T3 & T4 & T5 & T6 \\
\hline $\begin{array}{l}\text { Video with } \\
\text { information }\end{array}$ & $\begin{array}{l}\text { Physician } \\
\text { champion }\end{array}$ & $\begin{array}{c}\text { Communications } \\
\text { Toolkit }\end{array}$ & $\begin{array}{c}\text { Bundled } \\
\text { prescription form }\end{array}$ & $\begin{array}{l}\text { HPV prescription } \\
\text { form }\end{array}$ & $\begin{array}{l}\text { Third party } \\
\text { initiation }\end{array}$ & $\begin{array}{l}\text { Increasing } \\
\text { salience }\end{array}$ \\
\hline $\begin{array}{c}\text { unrelated to } \\
\text { cervical cancer } \\
\text { or the HPV } \\
\text { vaccine } \\
+ \\
\text { Infographic }\end{array}$ & $\begin{array}{c}\text { Video of } \\
\text { physician } \\
\text { champion } \\
+ \\
\text { Physician } \\
\text { champion } \\
\text { infographic }\end{array}$ & $\begin{array}{c}\text { Video } \\
\text { explaining the } \\
\text { strategies and } \\
\text { tips } \\
+ \\
\begin{array}{c}\text { Poster version } \\
\text { of the toolkit }\end{array}\end{array}$ & $\begin{array}{l}\text { Video showing } \\
\text { a physician } \\
\text { using the } \\
\text { prescription } \\
\text { form for } \\
\text { bundling the } \\
\text { HPV and } \\
\text { Td/Tdap } \\
\text { vaccines } \\
+ \\
\text { Prescription } \\
\text { form }\end{array}$ & $\begin{array}{l}\text { Video of a } \\
\text { physician having a } \\
\text { conversation with } \\
\text { a parent about the } \\
\text { HPV vaccine only, } \\
\text { using a } \\
\text { prescription form } \\
\text { with a column on } \\
\text { the side to set up } \\
\text { an appointment for } \\
\text { the HPV vaccine. } \\
\quad+ \\
\text { Prescription form }\end{array}$ & $\begin{array}{c}\text { Video of a } \\
\text { physician being } \\
\text { nudged by a } \\
\text { poster to have } \\
\text { a conversation } \\
\text { on the vaccine } \\
+ \\
\text { Poster creating } \\
\text { a sense of third } \\
\text { party initiation/ } \\
\text { monitoring }\end{array}$ & $\begin{array}{l}\text { Video with } \\
\text { cervical cancer } \\
\text { facts } \\
\text { emphasising } \\
\text { the risks and } \\
\text { incidence of } \\
\text { the disease and } \\
\text { the efficacy of } \\
\text { the vaccine }\end{array}$ \\
\hline
\end{tabular}

\section{Power Analysis}

To set expectations for sample size requirements, we refer to Hobma et al. (2006) and Clark et al. (1998), two studies that assess impact of communications skills training on improving doctor-patient communication. We found these studies to be close proxies for a quantitative evaluation of the impact of a communication skills intervention on how well doctors can communicate vital information and address misconceptions about treatments.

We conducted a power analysis for $80 \%$ power and an alpha of 0.05 using the power two means command on STATA 12 , with our estimate being as follows:

\begin{tabular}{|l|l|l|}
\hline Power & \multicolumn{2}{|c|}{0.80} \\
\hline Alpha & \multicolumn{2}{|c|}{0.05} \\
\hline \multirow{2}{*}{ Benchmark study used } & \multicolumn{1}{|c|}{ Case 1 } & \multicolumn{1}{|c|}{ Case 2 } \\
& $\begin{array}{ll}\text { Hobbma et al 2006 } \\
\text { Study sample: 100 General }\end{array}$ & $\begin{array}{l}\text { Clark et al 1998 } \\
\text { Study sample: } ~ 74 \text { General }\end{array}$ \\
\hline
\end{tabular}




\begin{tabular}{|c|c|c|}
\hline & $\begin{array}{l}\text { Physicians in the } \\
\text { Netherlands }\end{array}$ & Physicians in USA \\
\hline $\begin{array}{l}\text { Outcome and effect } \\
\text { size: } \\
\text { effect size benchmark } \\
\text { studies (SD) }\end{array}$ & $\begin{array}{l}\text { Information giving to } \\
\text { patients } \\
.37(.90)\end{array}$ & $\begin{array}{l}\text { Addressing fears about new } \\
\text { medication } \\
0.46 \text { (1) } \\
8\end{array}$ \\
\hline \multicolumn{3}{|l|}{ RESULTS } \\
\hline $\begin{array}{l}\text { Estimated per arm } \\
\text { sample }\end{array}$ & 93 & 75 \\
\hline $\begin{array}{l}\text { This means, we would } \\
\text { need: }\end{array}$ & $\begin{array}{l}\sim 90 \text { doctors per } \\
\text { experimental arm } \\
\text { Total: } \sim 630 \text { doctors } \\
\text { (7 experimental arms) }\end{array}$ & $\begin{array}{l}\sim 75 \text { doctors per experimental } \\
\text { arm } \\
\text { Total: } ~ 525 \text { doctors } \\
\text { (7 experimental arms) }\end{array}$ \\
\hline
\end{tabular}

Table 1: Power Calculations

\section{Outcome Measures}

Since our study is a field survey experiment where doctors are recruited, administered stimulus with pre and post measurements, we are unable to reliably measure actual changes in practice ${ }^{9}$ Instead, we focus on evaluating the interventions in terms of changes in intention to prescribe the vaccine, change in knowledge about HPV vaccines and cervical cancer, trust in safety and effectiveness of the vaccine, and self-efficacy and ease of communication for doctors in discussing and prescribing the vaccine. We also measure injunctive norms about the vaccine, as a mediator/ moderator.

Given that one real-world constraint was the length of time we can request from doctors for the study, we only measure previous prescription practice ${ }^{10}$ and intention from participants in the baseline.

\footnotetext{
${ }^{8} \mathrm{SD}$ not reported, we assume a value of 1 to be conservative.

${ }^{9}$ We do intend to reach out to participants one week after the experiment to measure any difference in practice outcomes, but given study constraints, we anticipate an underpowered analysis for the longer term practice outcomes

${ }_{10}$ We ask doctors to report the number of times they have prescribed the HPV and the $\mathrm{Td} /$ Tdap vaccine in the past week, along with how often they generally prescribe the vaccines and importance of the vaccine, as communicated to patients
} 
To delineate whether the stimulus has an impact only on HPV vaccine intention, or whether there is any spillover on general attitude towards vaccination, we repeat practice and intention questions for the Td/Tdap vaccine -- which is largely uncontroversial, and is widely prescribed throughout India, for the same age group as the HPV vaccine.

We will run two analyses with the outcomes that use Likert scale responses. The first analysis (M1) uses the likert scores, resulting in our dependent variables being categorical in nature. Our second analysis (M2) will create summative scores for specific constructs, indicating the number of 'positive' responses for that construct in the endline. We will use this score, which is now a discrete variable, as our dependent variable in our regression models. We describe the construction of these measures in Table 2. A codebook detailing all the variables and their description can be found here and on the pre-registration page.

\begin{tabular}{|c|c|c|c|}
\hline $\begin{array}{l}\text { Outcome } \\
\text { Variable }\end{array}$ & Description & Model 1 (Standard) & $\begin{array}{c}\text { Model } 2 \\
\text { (Summative } \\
\text { Score) }\end{array}$ \\
\hline $\begin{array}{l}\text { Endline: } \\
\text { Intentionality to } \\
\text { prescribe HPV } \\
\text { vaccine }\end{array}$ & $\begin{array}{l}\text { How often do you plan } \\
\text { to recommend the HPV } \\
\text { vaccine to } \\
\text { parents/guardians of } \\
\text { adolescent girls (aged } \\
9-14 \text { years) in your daily } \\
\text { routine in the future? }\end{array}$ & $\begin{array}{l}\text { Outcome measure } \\
\text { creation: } \\
\text { No manipulation } \\
\text { required. Use ordinal } \\
\text { variable as dependent } \\
\text { variable }\end{array}$ & NA \\
\hline $\begin{array}{l}\text { Endline: } \\
\text { Intentionality to } \\
\text { prescribe } \\
\text { Td/Tdap vaccine }\end{array}$ & $\begin{array}{l}\text { How often do you plan } \\
\text { to recommend the } \\
\text { Td/Tdap vaccine to } \\
\text { parents/guardians of } \\
\text { adolescent girls (aged } \\
9-14 \text { years) in your daily } \\
\text { routine in the future? }\end{array}$ & $\begin{array}{l}\text { Outcome measure } \\
\text { creation: } \\
\text { No manipulation } \\
\text { required. Use ordinal } \\
\text { variable as dependent } \\
\text { variable }\end{array}$ & NA \\
\hline $\begin{array}{l}\text { Endline: Safety } \\
\text { of vaccine }\end{array}$ & $\begin{array}{l}2 \text { statements on trust in } \\
\text { the safety and efficacy } \\
\text { of the HPV vaccine. } \\
\begin{array}{l}\text { 1. The HPV vaccine } \\
\text { is safe } \\
\text { 2. The HPV vaccine } \\
\text { is unlikely to } \\
\text { result in severe } \\
\text { adverse effects }\end{array}\end{array}$ & $\begin{array}{l}\text { Outcome measure } \\
\text { creation: } \\
\text { No manipulation } \\
\text { required. Use ordinal } \\
\text { variable as dependent } \\
\text { variable }\end{array}$ & $\begin{array}{l}\text { Outcome } \\
\text { measure } \\
\text { creation: } \\
\text { From } 2 \\
\text { statements } \\
\text { answered on } \\
\text { 7-point Likert } \\
\text { scale, count of } \\
\text { statements } \\
\text { with }\end{array}$ \\
\hline
\end{tabular}




\begin{tabular}{|c|c|c|c|}
\hline & for patients. & & $\begin{array}{l}\text { Likert-scale } \\
\text { response } 5 \text { and } \\
\text { above }{ }^{11}\end{array}$ \\
\hline $\begin{array}{l}\text { Endline: } \\
\text { Effectiveness }\end{array}$ & $\begin{array}{l}2 \text { statements on } \\
\text { effectiveness of the HPV } \\
\text { vaccine. } \\
\begin{aligned} \text { 1. The HPV vaccine } \\
\text { is effective in } \\
\text { preventing HPV } \\
\text { infections } \\
\text { 2. The HPV vaccine } \\
\text { prevents cervical } \\
\text { cancer. }\end{aligned}\end{array}$ & $\begin{array}{l}\text { Outcome measure } \\
\text { creation: } \\
\text { No manipulation } \\
\text { required. Use ordinal } \\
\text { variable as dependent } \\
\text { variable }\end{array}$ & $\begin{array}{l}\begin{array}{l}\text { Outcome } \\
\text { measure } \\
\text { creation: }\end{array} \\
\text { From } 2 \\
\text { statements } \\
\text { answered on } \\
\text { 7-point Likert } \\
\text { scale, count of } \\
\text { statements } \\
\text { with } \\
\text { Likert-scale } \\
\text { response } 5 \text { and } \\
\text { above }\end{array}$ \\
\hline $\begin{array}{l}\text { Endline: } \\
\text { Communication } \\
\text { Parents }\end{array}$ & $\begin{array}{l}9 \text { questions on } \\
\text { physicians' belief in } \\
\text { their confidence to have } \\
\text { conversations about the } \\
\text { vaccine with parents of } \\
\text { adolescent girls. } \\
\text { Statements are: } \\
\text { 1. Initiating } \\
\text { conversations } \\
\text { around the HPV } \\
\text { vaccine with } \\
\text { parents of } \\
\text { adolescent girls } \\
\text { (aged } 9-14 \text { years). } \\
\text { 2. Counselling } \\
\text { parents about } \\
\text { the safety and } \\
\text { effectiveness of } \\
\text { the HPV vaccine } \\
\text { for their } \\
\text { daughters. } \\
\text { 3. Convincing } \\
\text { parents to get } \\
\text { the HPV vaccine } \\
\text { for their } \\
\text { daughters. }\end{array}$ & $\begin{array}{l}\text { Outcome measure } \\
\text { creation: } \\
\text { No manipulation } \\
\text { required. Use ordinal } \\
\text { variable as dependent } \\
\text { variable }\end{array}$ & $\begin{array}{l}\text { Outcome } \\
\text { measure } \\
\text { creation: } \\
\text { From } 9 \\
\text { statements } \\
\text { answered on } \\
\text { 7-point Likert } \\
\text { scale, count of } \\
\text { statements } \\
\text { with } \\
\text { Likert-scale } \\
\text { response } 5 \text { and } \\
\text { above }\end{array}$ \\
\hline
\end{tabular}

\footnotetext{
"We count statements where participants respond with 'Somewhat Agree' and stronger on the 7-point Likert scale. All our response scales are arranged so that higher values are positive outcomes in terms of our hypotheses.
} 


\begin{tabular}{|c|c|c|c|}
\hline & $\begin{array}{l}\text { 4. Ensuring that the } \\
\text { parents of } \\
\text { adolescent girls } \\
\text { have all the } \\
\text { necessary } \\
\text { information } \\
\text { regarding the } \\
\text { HPV vaccine. } \\
\text { 5. Answering } \\
\text { parents' } \\
\text { questions on the } \\
\text { HPV vaccine. } \\
\text { 6. Making parents } \\
\text { feel comfortable } \\
\text { to discuss the } \\
\text { HPV vaccine. } \\
\text { Having } \\
\text { conversations } \\
\text { about the HPV } \\
\text { vaccine under a } \\
\text { time strain. } \\
\text { 8. How confident } \\
\text { you are in } \\
\text { carrying out } \\
\text { conversations } \\
\text { around the HPV } \\
\text { vaccine with } \\
\text { fathers of } \\
\text { adolescent girls. } \\
\text { How confident } \\
\text { you are in } \\
\text { carrying out } \\
\text { conversations } \\
\text { around the HPV } \\
\text { vaccine with } \\
\text { mothers of } \\
\text { adolescent girls. }\end{array}$ & & \\
\hline $\begin{array}{l}\text { Endline: } \\
\text { Knowledge }\end{array}$ & $\begin{array}{l}6 \text { multiple-choice } \\
\text { questions on key facts } \\
\text { regarding the HPV } \\
\text { vaccine }\end{array}$ & $\begin{array}{l}\text { Outcome measure } \\
\text { creation: } \\
\text { Count of number of } \\
\text { questions answered } \\
\text { correctly }\end{array}$ & NA \\
\hline $\begin{array}{l}\text { Endline: } \\
\text { Injunctive } \\
\text { Norms }\end{array}$ & $\begin{array}{l}4 \text { statements on which } \\
\text { behaviours around HPV } \\
\text { vaccine }\end{array}$ & $\begin{array}{l}\text { Outcome measure } \\
\text { creation: }\end{array}$ & $\begin{array}{l}\text { Outcome } \\
\text { measure } \\
\text { creation: }\end{array}$ \\
\hline
\end{tabular}




\begin{tabular}{|c|c|c|c|}
\hline & $\begin{array}{l}\text { recommendation are } \\
\text { considered appropriate } \\
\text { (or not) by physicians. } \\
\text { 1. Initiating } \\
\text { conversations on } \\
\text { the HPV vaccine } \\
\text { with parents. } \\
\text { 2. Counselling } \\
\text { patients on the } \\
\text { safety and } \\
\text { effectiveness of } \\
\text { the vaccine. } \\
\text { 3. Convincing } \\
\text { parents to get } \\
\text { the vaccine for } \\
\text { their daughters. } \\
\text { 4. Routinely } \\
\text { recommending } \\
\text { the HPV vaccine } \\
\text { to } 9 \text {-14 year old } \\
\text { girls. }\end{array}$ & $\begin{array}{l}\text { No manipulation } \\
\text { required. Use ordinal } \\
\text { variable as dependent } \\
\text { variable }\end{array}$ & $\begin{array}{l}\text { From } 4 \\
\text { statements } \\
\text { answered on } \\
\text { 7-point Likert } \\
\text { scale, count of } \\
\text { statements } \\
\text { with } \\
\text { Likert-scale } \\
\text { response } 5 \text { and } \\
\text { above }\end{array}$ \\
\hline $\begin{array}{l}\text { Endline: } \\
\text { Responsibility } \\
\text { for vaccine } \\
\text { adoption }\end{array}$ & $\begin{array}{l}\text { Please state how } \\
\text { responsible you feel in } \\
\text { encouraging the } \\
\text { adoption of the HPV } \\
\text { vaccine. }\end{array}$ & $\begin{array}{l}\text { No manipulation } \\
\text { required. Use ordinal } \\
\text { variable as dependent } \\
\text { variable }\end{array}$ & $\begin{array}{l}\text { No } \\
\text { manipulation } \\
\text { required. Use } \\
\text { ordinal variable } \\
\text { as dependent } \\
\text { variable }\end{array}$ \\
\hline $\begin{array}{l}\text { Endline: } \\
\text { Importance of } \\
\text { parental } \\
\text { attitudes }\end{array}$ & $\begin{array}{l}\text { Please rate how much } \\
\text { you agree with the } \\
\text { following statement: } \\
\text { I am more likely to } \\
\text { recommend the HPV } \\
\text { vaccine when parents } \\
\text { initiate conversations } \\
\text { on the vaccine }\end{array}$ & $\begin{array}{l}\text { No manipulation } \\
\text { required. Use ordinal } \\
\text { variable as dependent } \\
\text { variable }\end{array}$ & $\begin{array}{l}\text { No } \\
\text { manipulation } \\
\text { required. Use } \\
\text { ordinal variable } \\
\text { as dependent } \\
\text { variable }\end{array}$ \\
\hline $\begin{array}{l}\text { Follow-up: }{ }^{12} \\
\text { HPV vaccine } \\
\text { prescription } \\
\text { practice }\end{array}$ & $\begin{array}{l}\text { Number of HPV vaccine } \\
\text { prescriptions in past } \\
\text { week }\end{array}$ & $\begin{array}{l}\text { No manipulation } \\
\text { required. }\end{array}$ & NA \\
\hline
\end{tabular}

${ }^{12}$ Given that we expect a very low response rate to the follow-up survey, we do not expect to run a well-powered analysis on data from follow-up surveys. 


\begin{tabular}{|c|c|c|c|}
\hline $\begin{array}{l}\text { Follow-up: } \\
\text { Td/Tdap vaccine } \\
\text { prescription } \\
\text { practice }\end{array}$ & $\begin{array}{l}\text { Number of Td/Tdap } \\
\text { vaccine prescriptions in } \\
\text { past week }\end{array}$ & $\begin{array}{l}\text { No manipulation } \\
\text { required. }\end{array}$ & NA \\
\hline $\begin{array}{l}\text { Follow-up: } \\
\text { Frequency of } \\
\text { HPV vaccine } \\
\text { prescription }\end{array}$ & $\begin{array}{l}\text { How often do you plan } \\
\text { to recommend the HPV } \\
\text { vaccine to } \\
\text { parents/guardians of } \\
\text { adolescent girls (aged } \\
9-14 \text { years) in your daily } \\
\text { routine in the future? }\end{array}$ & $\begin{array}{l}\text { No manipulation } \\
\text { required. }\end{array}$ & NA \\
\hline $\begin{array}{l}\text { Follow-up: } \\
\text { Frequency of } \\
\text { Td/Tdap vaccine } \\
\text { prescription }\end{array}$ & $\begin{array}{l}\text { How often do you plan } \\
\text { to recommend the } \\
\text { Td/Tdap vaccine to } \\
\text { parents/guardians of } \\
\text { adolescent girls (aged } \\
\text { 9-14 years) in your daily } \\
\text { routine in the future? }\end{array}$ & $\begin{array}{l}\text { No manipulation } \\
\text { required. }\end{array}$ & NA \\
\hline $\begin{array}{l}\text { Follow-up: } \\
\text { Initiating } \\
\text { conversation } \\
\text { about HPV } \\
\text { vaccine }\end{array}$ & $\begin{array}{l}\text { How are conversations } \\
\text { with parents/guardians } \\
\text { of adolescent girls } \\
\text { about the HPV vaccine } \\
\text { usually initiated? }\end{array}$ & $\begin{array}{l}\text { No manipulation } \\
\text { required. }\end{array}$ & NA \\
\hline $\begin{array}{l}\text { Follow-up: } \\
\text { Strength of HPV } \\
\text { vaccine } \\
\text { prescription }\end{array}$ & $\begin{array}{l}1 \text { question on how } \\
\text { important the HPV } \\
\text { vaccine is: } \\
\text { When you recommend } \\
\text { the HPV vaccine, you } \\
\text { usually say it is }\end{array}$ & $\begin{array}{l}\text { No manipulation } \\
\text { required. }\end{array}$ & NA \\
\hline
\end{tabular}

Table 2: Outcome Variables 


\section{Covariates}

We measure standard demographic variables such as gender, age, religion, reservation category, income, and type of practice to use as controls. Since there is some evidence that vaccination attitudes are influenced by previously held beliefs ${ }^{13}$, we also measure participants' beliefs about key barriers to HPV vaccination, their trust in sources of information about the vaccine, as well as the descriptive norms around HPV vaccination amongst their peers.

\begin{tabular}{|c|c|c|}
\hline Type & Description & $\begin{array}{l}\text { Measure creation/ Final } \\
\text { variable used }\end{array}$ \\
\hline \multirow{7}{*}{ Endline: Demographics } & Age of respondent & $\begin{array}{l}\text { No manipulation } \\
\text { required }\end{array}$ \\
\hline & Gender of respondent & $\begin{array}{l}\text { Dummy variable taking } \\
\text { value } 1 \text { for female } \\
\text { and } 0 \text { for male }\end{array}$ \\
\hline & Religion of respondent & $\begin{array}{l}\text { Dummy variable taking } \\
\text { value } 1 \text { for non-hindu } \\
\text { and } O \text { for all other } \\
\text { religions }\end{array}$ \\
\hline & $\begin{array}{l}\text { Caste Reservation } \\
\text { category of } \\
\text { respondent }\end{array}$ & $\begin{array}{l}\text { Dummy variable taking } \\
\text { value } 1 \text { for } \\
\text { non-General } \\
\text { category and } 0 \text { for } \\
\text { general category } \\
\text { respondents }\end{array}$ \\
\hline & $\begin{array}{l}\text { Annual Income of } \\
\text { respondent in INR }\end{array}$ & $\begin{array}{l}\text { Logarithm of annual } \\
\text { income }\end{array}$ \\
\hline & $\begin{array}{l}\text { Practice Type (Public or } \\
\text { Private) }\end{array}$ & $\begin{array}{l}\text { No manipulation } \\
\text { required. Categorical } \\
\text { variable with } 3 \text { levels } \\
\text { (Public, Private or } \\
\text { Both) }\end{array}$ \\
\hline & Student/ non-student (If & Dummy variable taking \\
\hline
\end{tabular}

${ }^{13}$ Roberto, A. J., Krieger, J. L., Katz, M. L., Goei, R., \& Jain, P. (2011). Predicting pediatricians' communication with parents about the human papillomavirus (hpv) vaccine: an application of the theory of reasoned action. Health communication, 26(4), 303-312. https://doi.org/10.1080/10410236.2010.550021 


\begin{tabular}{|c|c|c|}
\hline & $\begin{array}{l}\text { respondent is a PG } \\
\text { resident doctor or } \\
\text { not) }\end{array}$ & $\begin{array}{l}\text { value } 1 \text { if respondent } \\
\text { is resident doctor } \\
\text { and } O \text { if not. }\end{array}$ \\
\hline & $\begin{array}{l}\text { Specialty of doctor } \\
\text { (General Physician, } \\
\text { Pediatrician, } \\
\text { Gynaecologist) }\end{array}$ & $\begin{array}{l}\text { No manipulation } \\
\text { required. Categorical } \\
\text { variable with } 3 \text { levels } \\
\text { (General Physician, } \\
\text { Pediatrician, } \\
\text { Gynaecologist) }\end{array}$ \\
\hline $\begin{array}{l}\text { Baseline: Relevance of } \\
\text { Barriers }\end{array}$ & $\begin{array}{l}\text { Explicit attitudes towards } \\
\text { the relevance of different } \\
\text { barriers in influencing the } \\
\text { recommendation process } \\
\text { at the physician, patient } \\
\text { and environmental level, } \\
\text { measured using } 5 \\
\text { statements on a 7-point } \\
\text { Likert scale }\end{array}$ & $\begin{array}{l}\text { No manipulation } \\
\text { required. We use } \\
\text { each of the } 5 \\
\text { variables as } \\
\text { covariates in the } \\
\text { analysis. }\end{array}$ \\
\hline Baseline: Descriptive norms & $\begin{array}{l}\text { Stated perceptions of } \\
\text { which behaviours around } \\
\text { HPV vaccine } \\
\text { recommendation are } \\
\text { typically performed by } \\
\text { physicians. } \\
\text { 1. My peers in the } \\
\text { medical community } \\
\text { support the HPV } \\
\text { vaccine for } \\
\text { adolescent girls } \\
\text { aged 9-14 years. } \\
\text { 2. Most physicians } \\
\text { initiate } \\
\text { conversations on the } \\
\text { HPV vaccine with } \\
\text { parents. } \\
\text { 3. Most physicians } \\
\text { counsel parents on } \\
\text { the safety and } \\
\text { effectiveness of the } \\
\text { HPV vaccine. } \\
\text { 4. Most physicians } \\
\text { convince parents to } \\
\text { get the HPV vaccine }\end{array}$ & $\begin{array}{l}\text { From } 4 \text { statements answered } \\
\text { on } 7 \text {-point Likert scale, count } \\
\text { of statements with } \\
\text { Likert-scale response } 5 \text { and } \\
\text { above }\end{array}$ \\
\hline
\end{tabular}




\begin{tabular}{|c|c|c|}
\hline & for their daughters. & \\
\hline $\begin{array}{l}\text { Baseline: Trust in } \\
\text { information sources of HPV } \\
\text { vaccine }\end{array}$ & $\begin{array}{l}\text { SOurces, about the HPV } \\
\text { vaccine: } \\
\text { 1. Govt institutions } \\
\text { 2. WHO } \\
\text { 3. UNICEF } \\
\text { 4. Medical Associations } \\
\text { 5. Medical literature } \\
\text { 6. Fellow medical } \\
\text { 7. Soers } \\
\text { 7. Social media }\end{array}$ & $\begin{array}{l}\text { For our standard model, } \\
\text { we use each of the } 7 \\
\text { variables as } \\
\text { covariates in the } \\
\text { analysis. } \\
\text { For our summative } \\
\text { scores model, we } \\
\text { create a dummy } \\
\text { variable (for each of } \\
\text { our } 7 \text { outcomes } \\
\text { here) taking value } 1 \\
\text { iff the response for } \\
\text { individual is equal to } \\
\text { or greater than } \\
\text { mean of all } \\
\text { responses, for that } \\
\text { specific variable. We } \\
\text { now sum up values } \\
\text { of these dummy } \\
\text { variables according } \\
\text { to the following } \\
\text { groupings: } \\
\text { Trust in formal } \\
\text { institutions: Govt } \\
\text { Institutions, WHO, } \\
\text { UNICEF } \\
\text { Trust in medical } \\
\text { community: Medical } \\
\text { Associations, Fellow } \\
\text { Medical peers, } \\
\text { Medical Literature } \\
\text { Trust in social media: } \\
\text { Social Media }\end{array}$ \\
\hline $\begin{array}{l}\text { Baseline: HPV prescription } \\
\text { practice }\end{array}$ & $\begin{array}{l}\text { Intention to prescribe the } \\
\text { HPV vaccine, on a 7-point } \\
\text { Likert scale } \\
\text { Stated HPV prescription } \\
\text { frequency, on a 7-point } \\
\text { Likert scale } \\
\text { Importance of HPV vaccine, } \\
\text { as told to patients, on a }\end{array}$ & $\begin{array}{l}\text { For our standard model, } \\
\text { we will use these } \\
\text { covariates as they } \\
\text { are, as ordinal } \\
\text { variables. } \\
\text { For our summative } \\
\text { score model, we will } \\
\text { create a new } \\
\text { variable that is the } \\
\text { count of number of }\end{array}$ \\
\hline
\end{tabular}




\begin{tabular}{|c|c|c|}
\hline & 7-point Likert scale & $\begin{array}{l}\text { statements out of } \\
\text { these that have } \\
\text { value } 5 \text { or greater }\end{array}$ \\
\hline & $\begin{array}{l}\text { Who initiates HPV vaccine } \\
\text { discussion -- doctor or } \\
\text { parents? }\end{array}$ & $\begin{array}{c}\text { Dummy variable, taking } \\
\text { value } 0 \text { if somebody } \\
\text { other than doctor } \\
\text { initiates discussion }\end{array}$ \\
\hline & $\begin{array}{l}\text { Number of HPV vaccine } \\
\text { prescriptions made in past } \\
\text { week }\end{array}$ & $\begin{array}{l}\text { No manipulation } \\
\text { required, use as } \\
\text { discrete variable }\end{array}$ \\
\hline & $\begin{array}{l}\text { Average appointment time, } \\
\text { and average time spent } \\
\text { talking about HPV, in } \\
\text { minutes }\end{array}$ & $\begin{array}{l}\text { Proportion of time } \\
\text { spent talking about } \\
\text { HPV in the average } \\
\text { appointment }\end{array}$ \\
\hline \multirow[t]{2}{*}{$\begin{array}{l}\text { Baseline: Td/Tdap } \\
\text { prescription practice }\end{array}$} & $\begin{array}{l}\text { Intention to prescribe the } \\
\text { Td/Tdap vaccine, on a } \\
\text { 7-point Likert scale } \\
\text { Stated Td/Tdap } \\
\text { prescription frequency, on } \\
\text { a 7-point Likert scale } \\
\text { Importance of HPV vaccine, } \\
\text { as told to patients, on a } \\
\text { 7-point Likert scale }\end{array}$ & $\begin{array}{l}\text { For our standard model, } \\
\text { we will use these } \\
\text { covariates as they } \\
\text { are, as ordinal } \\
\text { variables. } \\
\text { For our summative } \\
\text { score model, we will } \\
\text { create a new } \\
\text { variable that is the } \\
\text { count of number of } \\
\text { statements out of } \\
\text { these that have } \\
\text { value } 5 \text { or greater }\end{array}$ \\
\hline & $\begin{array}{l}\text { Number of Td/Tdap vaccine } \\
\text { prescriptions made in past } \\
\text { week }\end{array}$ & $\begin{array}{l}\text { No manipulation } \\
\text { required, use as } \\
\text { discrete variable }\end{array}$ \\
\hline
\end{tabular}

Table 3: Control Variables

\section{Empirical Analysis}

\section{Treatment Effects}

We will estimate differences in outcome across treatment and control arms using the following specifications: 


$$
\begin{aligned}
Y= & \alpha+\beta * \text { treatment.assigned }+\varepsilon \\
Y= & \alpha+\beta * \text { treatment.assigned }+\gamma * \text { demographic.covariates }+\tau * \text { behavioral.covariates }+\varepsilon \\
Y= & \alpha+\beta * \text { treatment.assigned }+\gamma * \text { demographic.covariates }+\tau * \text { behavioral.covariates } \\
& +\pi * \text { baseline.practice }+\varepsilon
\end{aligned}
$$

$\boldsymbol{Y}$ belong to the outcome measures described in Table 2.

treatment.assigned is an indicator variable for which experimental arm the subject was assigned.

demographic.covariates are demographic variables measured at baseline (barriers, norms, trust in info sources).

behavioral.covariates are control variables measured at baseline such as barriers to recommendations, existing norms, trust in information sources.

baseline.practice are measures of the intentions and practices associated with HPV and $\mathrm{Td} / \mathrm{Td}$ ap vaccine prescription at the baseline.

\section{Model Specifications}

We intend to report results using the following two models.

1. Standard model:

In this case, we run regressions using our raw outcome measures, with and without our control variables. We will either use an OLS model or an Ordered Logistic Model, depending on whether the dependent variable is discrete/continuous or an ordinal variable.

a. Basic OLS: We use OLS for outcomes where the response is a discrete variable, such as number of knowledge questions answered correctly.

b. Ordered Logit regression: We will use an ordered logistic model for our dependent variables that use Likert scores, e.g. intention to prescribe vaccine (Never, Rarely, Occasionally, Sometimes, Frequently, Usually Always), safety of the vaccine (Strongly disagree, Disagree, Somewhat disagree, Neither agree nor disagree, Somewhat agree, Agree, Strongly agree), etc.

2. Summative score model:

In this case, we use the new constructed variables, described in Table 2 , column 3, as our dependent variables in our treatment effects estimation. This approach allows us to condense multiple survey questions into a score which allows us to estimate the number of positive responses at individual level. We 
will use an OLS model to estimate differences in the number of positive responses, across the treatment conditions.

\section{Balance Checks}

We will check for balance between treatment and control groups for baseline attitudes towards vaccine hesitancy and demographic variables, these are listed in Table 3.

If $X$ is the measure of interest, the balance check specification will then be:

$X=\alpha+\beta *$ treatment.assigned $+\varepsilon$

\section{Attrition Analysis}

To check if respondents who dropped out of the study between the baseline and the practice-focused delayed endline sample are balanced by study arm, we will run the balance check using 'individuals attrited from sample' as our outcome measure. This model tells us if any of our baseline covariates or treatment assignment, can predict if a respondent drops out of the study.

If $Z$ is a dummy variable indicating if the respondent finished the baseline, but dropped off before completing the endline, the attrition analysis specification will be:

$Z=\alpha+\beta *$ treatment.assigned $+\gamma$. baseline.covariates $+\varepsilon$

\section{Robustness Checks}

Multiple hypothesis testing is a concern for our study, given that we are estimating 744 treatment effects (31 outcomes $\times 6$ treatments $\times 4$ models). At a 95\% level of confidence, we would expect $5 \%$ of these 744 tests (about 37 ) to show a significant difference between groups on average, just by chance. We will address this by computing and reporting Anderson's sharpened q values.

\section{Data Collection}

Data has been collected in two phases. In Wave 1, we piloted the instrument and our protocols with a set of 61 doctors in Kolkata city, in the state of West Bengal. Doctors in this wave of the study were incentivised with a certificate and Amazon Gift Cards 
worth INR 1000. We will include these responses in the dataset for our final analysis as well ${ }^{14}$.

In Wave 2, we intend to collect data with the support of a field team that will conduct in-person recruitment of 550 doctors (30\% general practitioners, 40\% pediatricians and 30\% gynaecologists) in Kolkata and 3-4 of its neighbouring districts in West Bengal.

There will be a total of 10 enumerators, led by 4 supervisors, who will be approaching doctors at their clinics/hospitals to seek their consent for willingness to participate.

Following are the steps that will be followed:

1. Enumerator will introduce the study to the doctor and will present a letter provided by CSBC broadly outlining the study objective and the request for participation.

2. Once the doctor confirms willingness to participate, the enumerator will send the survey link to the doctor via WhatsApp/Email/SMS. Alternatively, the enumerator will share his/her own tablet with the survey (based on the preference of the doctor).

3. Upon opening the survey, participants will first read and provide informed consent. If participants do not provide consent, the survey will be terminated and no additional responses will be collected.

4. Participants will then fill the baseline questionnaire, will be randomized, after which they will view the intervention and answer the endline questionnaire. The intervention stimulus includes a video and a poster.

5. Once the survey has been completed, participants will be given a pre-defined participation fee of Rs. 1000 for the two specialties, and Rs. 500 for GPs.

6. Participants will receive an automatic confirmation on their email address once they complete the survey.

7. Simultaneously, enumerators will request the doctor for their medical registration number (known as the $\mathrm{MCl}$ number) for verification. Alternatively, if the $\mathrm{MCl}$ number is not readily available, the enumerators will request for a photograph of the doctor's prescription form or their premises. The enumerators will add these details to a separate google form created for tracking purposes.

8. After a lag of one week, the participants will be sent the follow-up survey through SMS as well as email. As an incentive for this, participants will be informed that upon completion of this survey, they will be entered into a lottery where two of them will have a chance to win Rs. 10,000 each.

9. Reminders will be sent to participants to complete the follow-up survey

\footnotetext{
${ }^{14}$ We ran preliminary analyses, using OLS specifications, on the first 52 doctors to take part in the pilot roll-out.
} 
10. Certificates of participation will be shared with all those who complete the main survey.

The supervisors of the enumerators will conduct spot-checks for $10 \%$ of the sample and telephonic back-checks for 30\%. Additionally, the researchers of the study will also conduct telephonic backchecks with $30 \%$ of the participants.

All collected data will be scrutinized daily for inconsistencies in order to ensure data quality. 